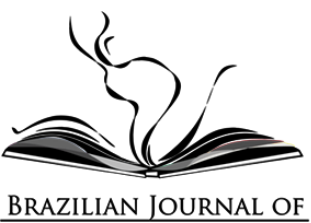

\title{
PATTERNS OF RESPONSES TO COVID-19 IN SELECTED LATIN AMERICAN COUNTRIES
}

\author{
PADRÕES DE RESPOSTAS AO COVID-19 EM PAÍSES SELECIONADOS DA \\ AMÉRICA LATINA
}

PATRONES DE RESPUESTA A LA COVID-19 EN PAÍSES SELECCIONADOS DE AMÉRICA LATINA

Thiago Brandão Peres'

Fundação CEPERJ, Brazil Adalberto Cardoso ${ }^{2}$ (D)

Universidade do Estado do Rio de Janeiro, Brazil

\begin{abstract}
The article analyses structural and context constraints and opportunities faced by Latin America in the battle against the Covid-19 pandemic. We argue that the number of deaths (and related statistics, such as number of infected or number of tests) as a proportion of the countries' populations is an important but insufficient measure of the effectiveness of each country's responses to the SARS-CoV-2 pandemic. We test the correlation of deaths with typical structural constraints (Gross domestic product, United Nation - Human Development Index, Gini index, expenditure in health, children's mortality rate, informality rate), and find that the differences between countries based on these measures do not help to understand the number of deaths per million inhabitants. We then move to a more in-depth analysis of 11 selected Latin American countries to show that those that chose collective responsibility (a notion developed in
\end{abstract}

\footnotetext{
'PhD in Sociology by the Institute of Social and Political Studies (IESP- UERJ) with the doctoral thesis: 'From fervor to fever: entrepreneurship, its origins and representations'. Sociologist at the State Center for Statistics, Research and Training of Civil Servants of Rio de Janeiro (CEPERJ). Email: thiagobrandaoperes@gmail.com

$2 \mathrm{PhD}$ in Sociology by the University of São Paulo (USP). Associate Professor at Institute of Social and Political Studies (IESP- UERJ). Email: acardoso@iesp.ueri.br
}

Cadernos Prolam/USP-Brazilian Journal of Latin American Studies, v. 20, n. 40, p. 23-56, out. 2021

Edição especial: Trabalho e proteção social na América Latina: desenvolvimentos recentes e os desafios diante da crise pandêmica. ISSN: 1676-6288 
the article) in the management of the responses to the crisis, and that could coordinate the actions of different governing levels, fared much better than those that chose individual responsibility and low levels of coordination, irrespective of existing structural constraints.

Keywords: Covid-19; Latin America; Collective Responsibility; Individual Responsibility; Coordination.

Resumo: $O$ artigo analisa as restrições estruturais e contextuais, e as oportunidades enfrentadas pela América Latina na batalha contra a pandemia de Covid-19. Argumentamos que o número de mortes (e estatísticas relacionadas, como número de infectados ou número de testes) como proporção das populações dos países é uma medida importante, mas insuficiente da eficácia das respostas de cada país ao SARS-CoV-2. Testamos a correlação de mortes com restrições estruturais típicas (Produto interno bruto, Índice de Desenvolvimento Humano, coeficiente de Gini, gastos com saúde, taxa de mortalidade infantil, taxa de informalidade) e descobrimos que as diferenças entre os países nessas medidas não são suficientes para explicar o número de mortes por milhão de habitantes. Em seguida, passamos a uma análise mais aprofundada de 11 países latino-americanos selecionados para mostrar que aqueles que escolheram a responsabilidade coletiva (noção desenvolvida no artigo) na gestão das respostas à crise, e que coordenaram as ações de diferentes níveis de governo, se saíram muito melhor do que aqueles que escolheram a responsabilidade individual e frouxa coordenação, independentemente das restrições estruturais existentes.

Palavras-chave: Covid-19; América Latina; Responsabilidade Coletiva; Responsabilidade Individual; Coordenação.

Resumen: El artículo analiza las limitaciones y oportunidades estructurales y de contexto que enfrenta América Latina en la batalla contra la pandemia de Covid-19. Argumentamos que el número de muertes (y estadísticas relacionadas, como el número de infectados o el número de pruebas) como proporción de la población de los países es una medida importante pero insuficiente de la efectividad de las respuestas de cada país al SARS-CoV-2. Probamos la correlación de las muertes con las limitaciones estructurales típicas (producto interno bruto, Índice de Desarrollo Humano, índice de Gini, gasto en salud, tasa de mortalidad infantil, tasa de informalidad) y encontramos que las diferencias entre países en estas medidas no son suficientes para explicar el número de muertes por millón de habitantes. Luego pasamos a un análisis más profundo de 11 países latinoamericanos seleccionados para mostrar que aquellos que eligieron la 
responsabilidad colectiva (una noción desarrollada en el artículo) en la gestión de las respuestas a la crisis, y que coordinaran las acciones de diferentes niveles de gobierno, obtuvieron mejores resultados que aquellos que eligieron la responsabilidad individual y baja coordinación, independientemente de las limitaciones estructurales existentes.

Palabras clave: Covid-19; América Latina; Responsabilidad Colectiva; Responsabilidad Individual; Coordinación.

\section{Introduction}

On March 11, 2020, the World Health Organization (WHO) declared the SARS-Cov-2 pandemic, and the director-general of the institution anticipated to the world's political authorities the verbs that would be crucial in the fight against the new virus: "If countries detect, test, treat, isolate, trace, and mobilize their people in the response, those with a handful of cases can prevent those cases becoming clusters, and those clusters becoming community transmission ${ }^{3}$

In May 2020, Latin America became one of the global epicenters of the pandemic ${ }^{4}$. Throughout this period, a proxy has become universal to diagnose either the effectiveness of the policies adopted by each country, or the size of the tragedy within their borders: the number of deaths (per 100 thousand or per million inhabitants). And this proxy is often the main parameter of comparisons between countries, that attests the proximity to, or distance from WHO verbs denoting good practices against the pandemic.

${ }^{3}$ See https://www.who.int/director-general/speeches/detail/who-director-general-s-opening-remarks-at-the-medi a-briefing-on-covid-19---11-march-2020 (accessed May 2021).

${ }^{4}$ In March 2021 Latin America was the worst performing continent according to the Covid Performance Index. See https://interactives.lowyinstitute.org/features/covid-performance/ (accessed May 2021). 
We have reasons to question the heuristic value of using only the number of deaths to measure the success or failure of a country's institutional responses. We will argue that, taken in isolation (or observed along with other related variables such as testing, confirmed cases, degree of social distancing, etc.), the number of deaths may underestimate the preconditions that constrained the countries' ability to prevent or delay community transmission of the virus.

Based on the Latin American case, we will show that prevailing political contexts, income inequality and informality conditioned the way SARS-Cov-2 landed in the region. Nonetheless, important as they are, these constraints are not sufficient to the understanding of the varying consequences of the pandemic in the Region. The second line of our argument examines a sample of 11 Latin American countries in the light of the notion of responsibility. Combining selected structural indicators with context analysis, our goal is to assess and classify the institutional responses to the pandemic of this set of countries. Our hypothesis is that, irrespective of structural and episodical constraints, collective responsibility is more effective in saving lives than individual responsibility ${ }^{5}$, particularly when combined with coordination of actions of different governing levels.

\section{Latin America \& the Caribbean: what is the heuristic value of death as a proxy?}

Latin America \& the Caribbean have only 8.2\% of the world population (approximately 645 million inhabitants), but concentrate about $18.5 \%$ of the confirmed cases, and $26.3 \%$ of deaths from the new coronavirus in the world. This denotes the dimension of the tragedy faced by Latin Americans. However, the continent is very unequal, and the finding that it has the worst performance in combating the pandemic in the world hides marked differences between countries. If Brazil today (September 2021) ranks

\footnotetext{
${ }^{5}$ We discuss these two models of responsibility in section 3.
} 
second in terms of deaths in the world, Uruguay does as well as the best performing countries, and several Central American and Caribbean countries have also managed to efficiently control the pandemic's effects. The relevant data are shown in Table $1^{6}$. How to explain these differences?

As in the case of other regions of the planet, Latin American governments had to deal with structural socioeconomic (that is, prior to the pandemic) and context conditions that constrained their actions (as well as civil society's) in combating the health crisis. Available literature has shown that it is necessary to associate the Covid-19 numbers with other indicators, while also keeping a close eye on each country's political context 7. As we will argue, government leadership and coordination have played and continue to play a fundamental role both in the elaboration of policies to control the community transmission of the virus, and in the orientation of conducts that, on the contrary, may have increased its spread. But structural aspects cannot be overlooked.

Table 1 - Number of dead per million inhabitants until Sept. 2020, in 27 L. American countries

\begin{tabular}{c|c|c|c|c|c}
\hline Country & Deaths & Country & Deaths & Country & Deaths \\
\hline Peru & 877,8 & Honduras & 190,6 & Belize & 32,7 \\
Chile & 592,2 & Dominican Rep. & 160,2 & Barbados & 24,4 \\
Brazil & 576,8 & Guatemala & 155,1 & Nicaragua & 21,3 \\
Mexico & 506,0 & Bahamas & 127,2 & Trin. \& Tob. & 19,3 \\
Panama & 467,7 & Suriname & 122,7 & Haiti & 17,6 \\
Bolivia & 437,0 & El Salvador & 111,6 & Venezuela & 13,8 \\
Colombia & 394,0 & Costa Rica & 87,0 & Uruguay & 12,7 \\
Ecuador & 372,4 & Guyana & 52,1 & Cuba & 8,4 \\
Argentina & 197,3 & Paraguay & 48,8 & Jamaica & 7,1 \\
\hline
\end{tabular}

\footnotetext{
${ }^{6}$ We chose to present mortality data up to September 2020 , due to the emergence of a second wave in several countries starting in October, which made the picture even more complex in terms of mortality trends and public policies to tame the disease.

${ }^{7}$ For instance, Fukuyama (2020), Rocha et al. (2021), Tetelboin et al. (2021).

${ }^{8}$ We present data for all L. A. countries available at the WHO datasets.
} 
If this is usually true, the first and most striking thing to mention is that the differences between L. A. countries cannot be attributed to the 'usual suspects', that is, standard structural variables such as variation in the countries' Gross Domestic Products (GDP), expenditures in health as a proportion of GDP, standard of living as measured, for instance, by the mortality rate of children at the age of 0-4 years (a strong indicator of the health and sanitary conditions of the poorer strata of the population), and others of the same sort. Structural constraints are always important, for they set the boundaries for governments' actions, but it is disturbing to find out that the richer countries in the Region (Chile, Argentina, Colombia, Brazil, and Mexico), and that spend more in public health as a proportion of their GDP, fared much worse than poorer countries (such as Cuba, Nicaragua, or Paraguay) in terms of number of infected and dead. Consequently, the correlation of these variables and the number of dead by Covid-19 is null, or close to null (Graph 1). Only the United Nations' Human Development Index (UN - HDI) presents a visible (but still very low) correlation with the number of deaths per million people, and in a counterintuitive way: the correlation is positive, meaning that the higher the rank, the higher the rate of deaths per million. 


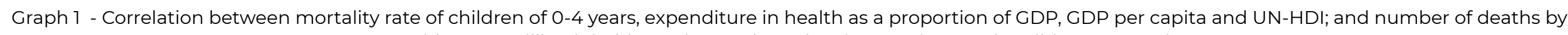
Covid-19 per million inhabitants in 25 selected Latin-American and Caribbean countries

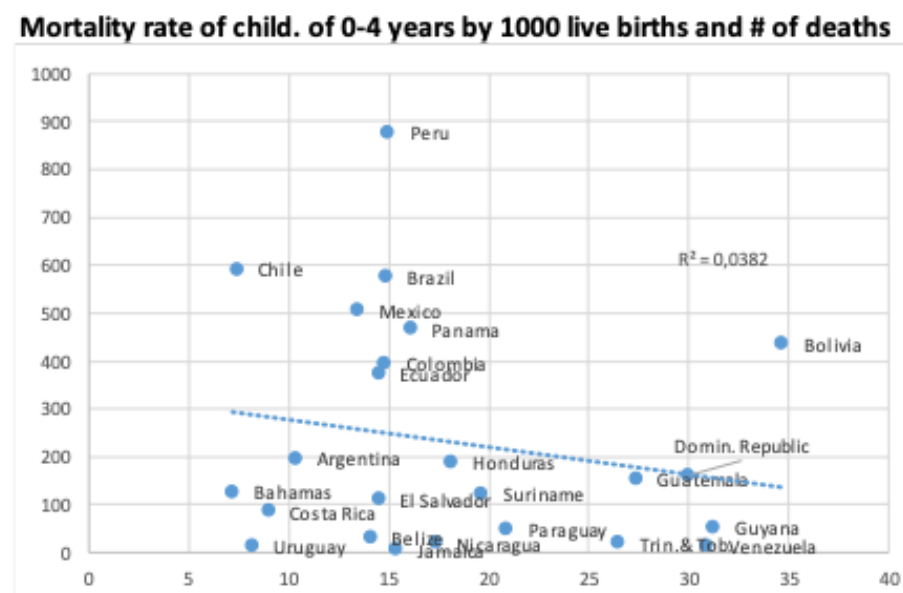

Source: WHO (data on child death from 2017)

\section{GDP per capita (thousand dollars) and \# of deaths}

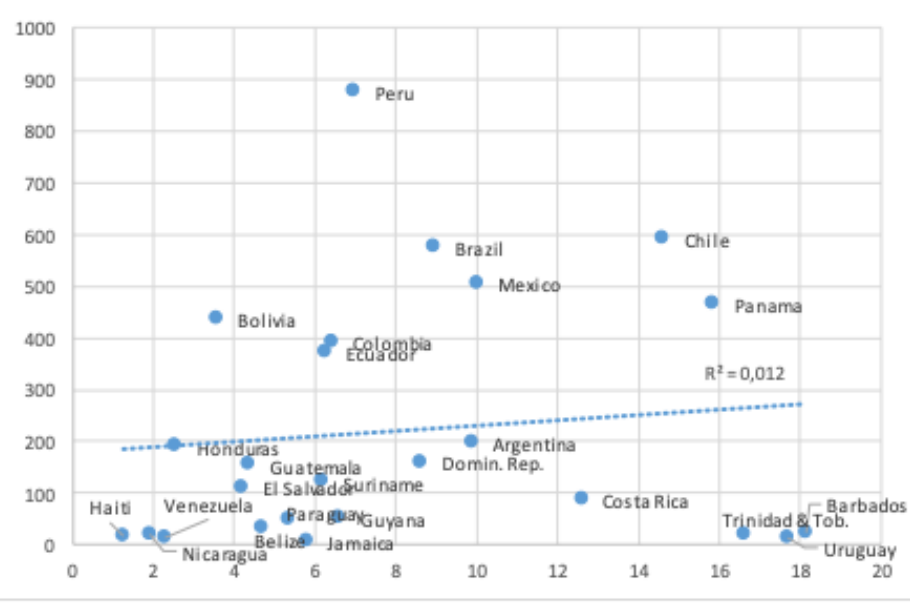

Source: IMF (data on GDP from 2019)

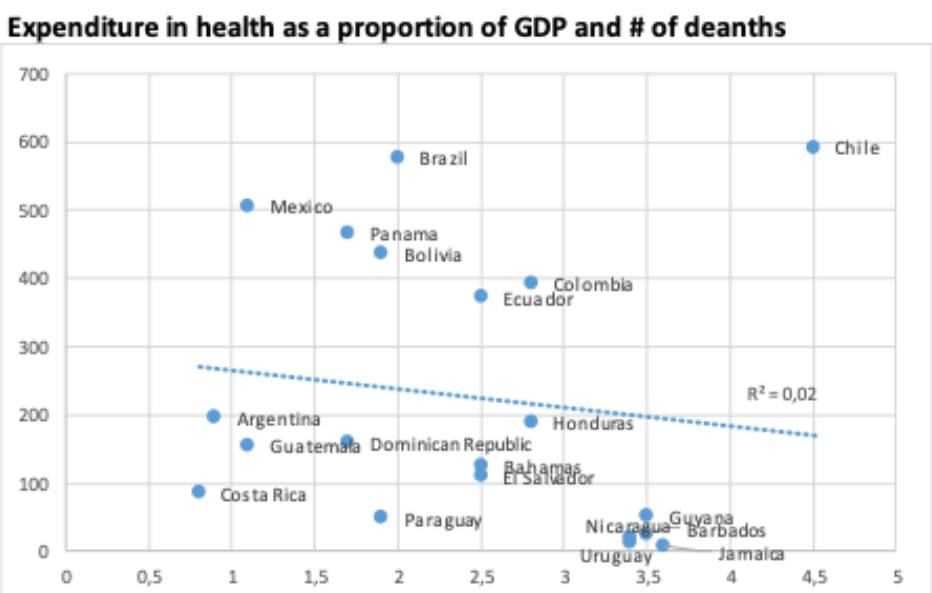

Source: CEPAL (data on expenditure is from 2016)

\section{Human Development Index (HDI) and \# of deaths}

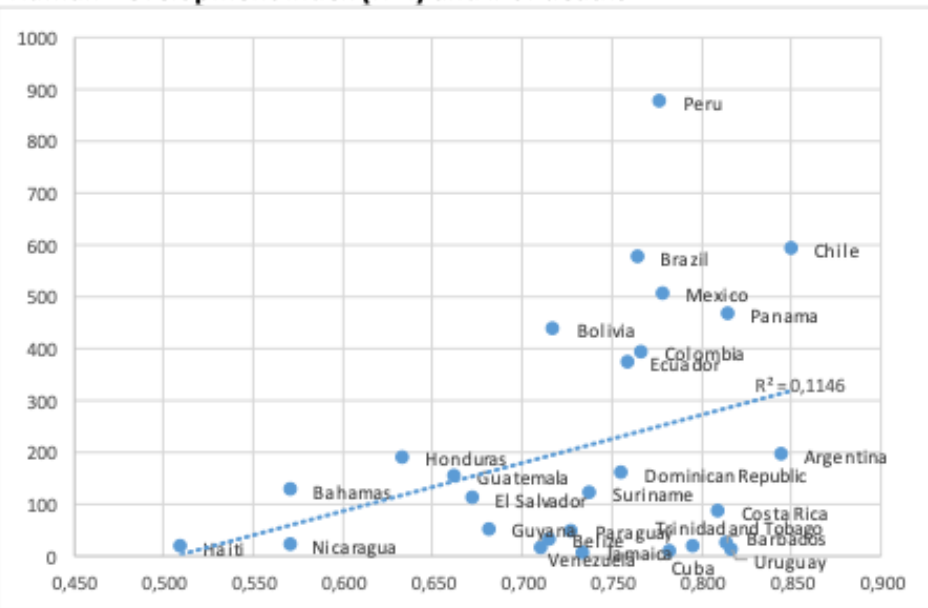

Source: United Nations

Note: Expenditure in Health available for 20 countries only. Deaths until Sept. 2020 are in the $Y$ axis). 
In the same direction, at the end of 2019 the Johns Hopkins Center for Health Security, in partnership with the Nuclear Threat Initiative, published the Global Health Security Index (NUCLEAR THREAT [...], 2019), which ranked the countries according to their ability to identify and mitigate possible health outbreaks. For our purposes, we crossed two dimensions (Graph 2): on the Y-axis is the set of variables that evaluate each country's health system ('Sufficient and robust health system to treat the sick and protect health workers'), such as the volume and distribution of clinics, hospitals and community service centers, and health professionals, infrastructure with availability of equipment and the ability to test and approve measures based on the results of the tests, etc.; on the $X$ axis we have the set of variables related to the 'Rapid response to and control of the spread of an epidemic', which assesses the (presumed) ability to respond to health emergencies (in general, it measures the communication between public health specialists and public authorities).

A reasonable hypothesis would assume that countries ranked higher in the index would be more able to adequately respond to the pandemic and, conversely, countries ranked lower would be more at the mercy of the virus. But this hypothesis is easily rejected by available evidence for Latin America. 
Graph 2 - Position of selected Latin American and Caribbean countries in relation to other countries in the sample according to X) the capacity to respond to a health emergency, and $Y$ ) the infrastructure of the health system.

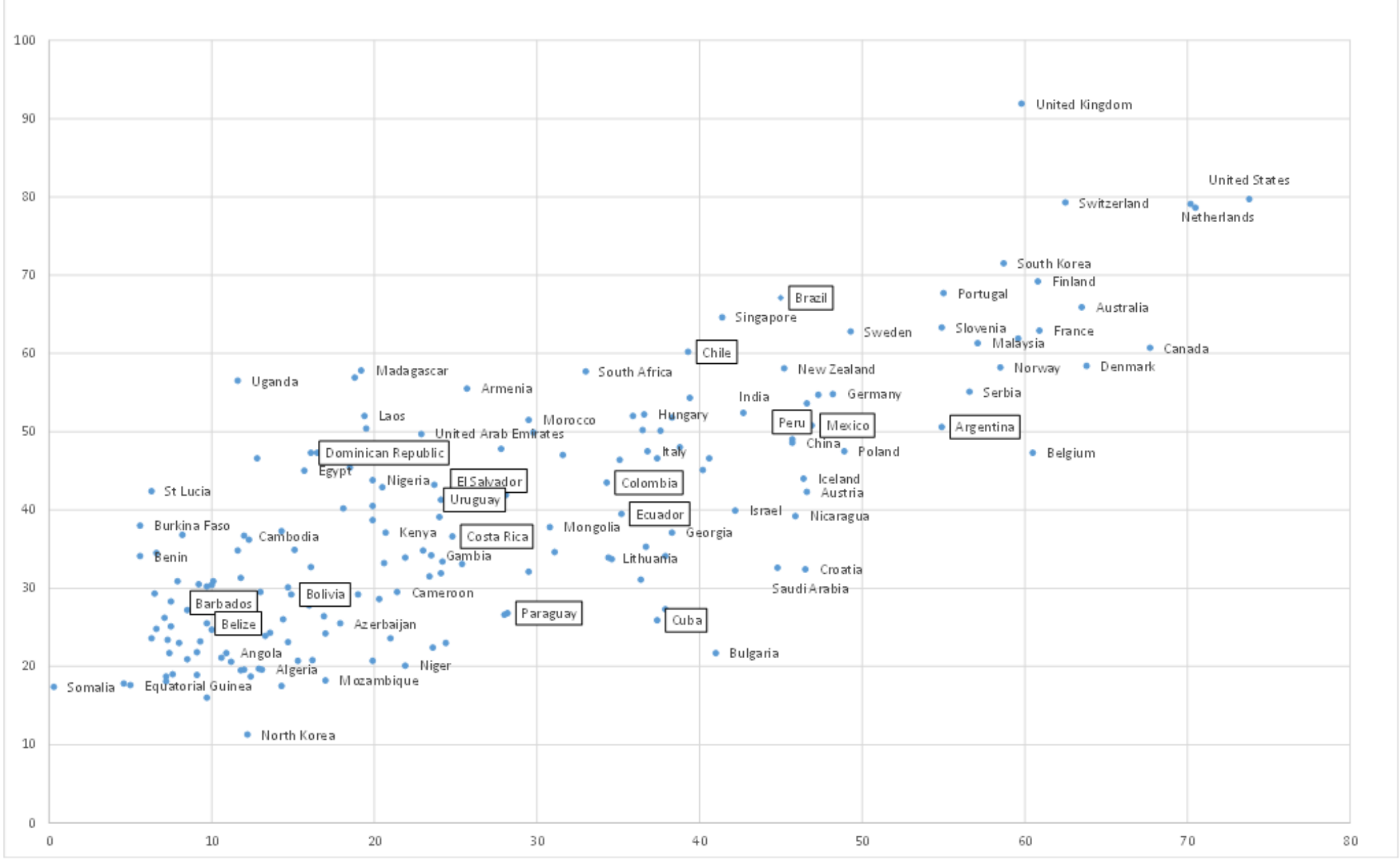

Source: Global Health Security Index. October 20199. Correlation: 0,78.

${ }^{9}$ Data in https://www.ghsindex.org/ (accessed Sept. 2021). 
In fact, Graph 3 correlates L.A. countries' average position in the variables 'Health System' and 'Rapid response' (Axis X) with the number of deaths per million inhabitants (Axis $Y$, data for September 2020 ${ }^{10}$ ). We see that the countries with the highest scores in the GHS Index variables are also the ones with the highest proportional number of deaths (especially Mexico, Chile, Brazil and Peru). That is, it is at least disturbing that the number of deaths per million does not respond inversely to the presence in the country of an infrastructure of (presumed) excellence in public health, abundance in human resources, capillarity of the public network and fluent communication between public administrators and health specialists.

10 We used the death data for the sixth month of the incidence of the new coronavirus in Latin America \& the Caribbean because we understand that this is sufficient to measure the efficiency of the infrastructure. And also, because the new wave beginning October 2020 dramatically changed the trends of the first wave. 
Graph 3 - Relation between the position in the GHS Index and number of deaths per million inhabitants in Latin America.

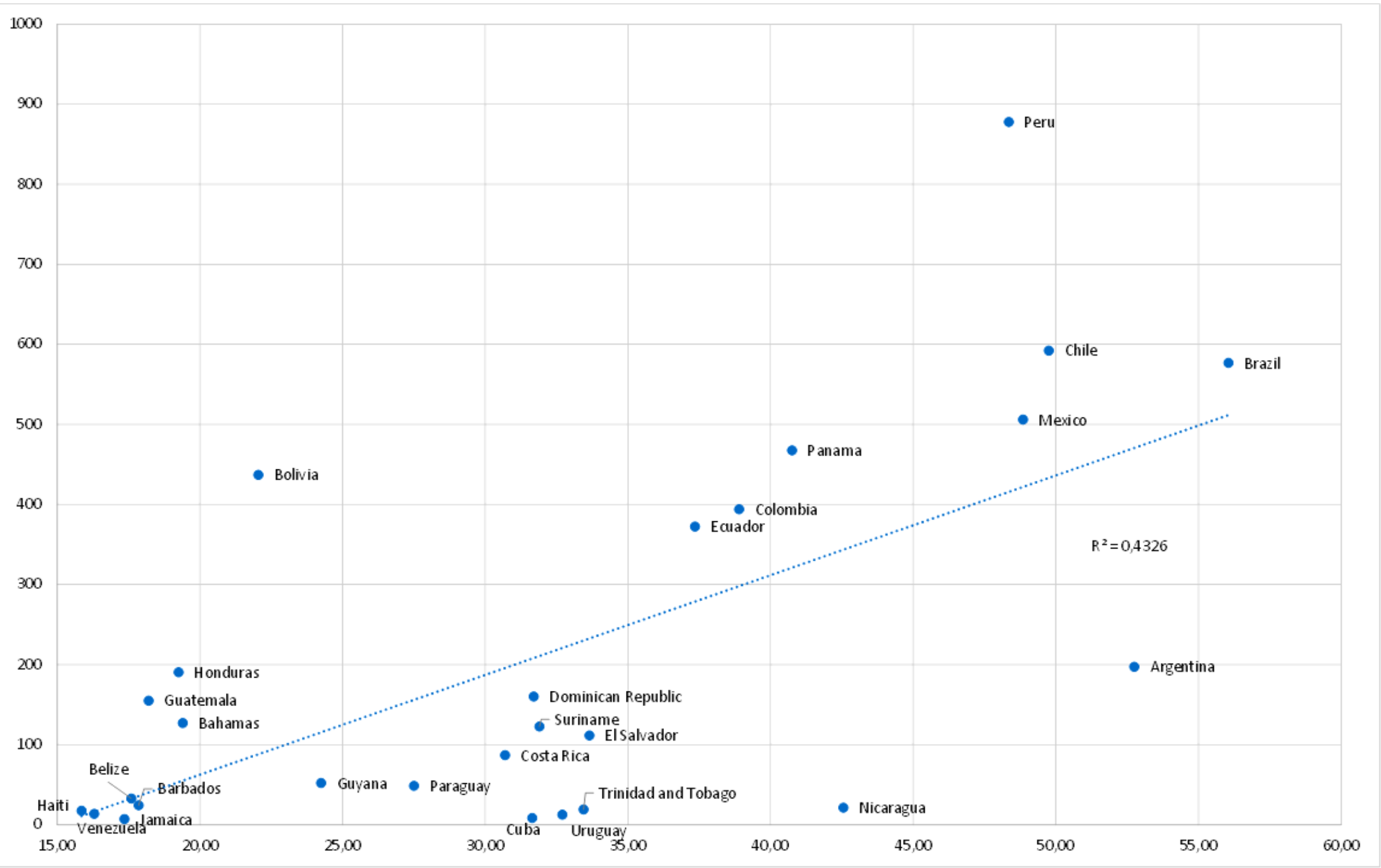

Source: Global Health Security Index, October 2019. OurWorldInData, Sept. 2020.

Note: GHS Index is in the X-axis. 
Not surprisingly, it turns out that the OECD countries' scores on the Index are also uncorrelated with their success or failure in taming the pandemic (ABBEY et al., 2020)". Abbey et al. bring two considerations to their conclusion. The first discusses the possibility that the GHS Index underestimates the indicators of some countries and overestimates those of others. But the authors do not say which countries, nor do they estimate the sources of one error or another, which reduce the strength of the argument. Any synthetic index is subject to estimation problems and can be improved, a challenge the authors face only partially. This leads us to the second consideration, which we consider more promising:

The expert panel should consider reassessing the GHS index frequently, including the potential incorporation of the effect of leadership in subsequent reports, since this appears to have contributed to the successful responses observed in countries like New Zealand and South Korea (ABBEY, 2020, p.9).

And we add its obverse, that is, we suggest that the 'leadership effect' also seems to have played a crucial role in the failure to manage the pandemic.

In other words, the aggregated data compiled so far suggest that, to understand the dynamics of the spread of the virus in Latin America and its consequences, we need other indicators and, above all, a complementary approach, which should include qualitative aspects in coping with the health crisis, among which the different government strategies seem decisive. The countries' levels of wealth, their human development index'2, the degree of investment in health and hospital infrastructure and qualified personnel, etc., while important, do not seem to be decisive in explaining the

\footnotetext{
${ }^{11}$ In fact, predictions using similar data failed blatantly in other circumstances. Asongu; Diop; and Nnanna (2020), for example, create a health vulnerability index (HVI) and leverages on an existing economic resilience index (ERI), and rank a sample of 150 countries in 5 continents according to their performance in each index. They conclude that almost all European countries, one African country (Rwanda), in the Americas USA, Argentina, Panama, Costa Rica, Uruguay and Canada, in Asia Japan, China, South Korea and Thailand were in the best position to face the virus. Nonetheless, they correctly predicted less than $50 \%$ of the cases, blatantly failing to predict most European countries, and the United States.

${ }_{12}$ The HDI is an index that takes life expectancy at birth, literacy, enrollment rates of school-age populations, and GDP per capita into account. But it is known that in a pandemic such as the one we are analyzing, elements such as age distribution of the population (Covid-19 affects, or affected until the second wave, especially older people), prevalence of comorbidities, type of prevalent comorbidities, etc., are important in differentiating between countries. We cannot deal with these issues here. But see Rocha et al. (2021)
} 
differences in terms of mortality during the pandemic. That is, countries in similar conditions of material well-being have suffered quite different impacts. And, within countries, the impacts were also quite uneven.

\section{Structural and context constraints: social inequality, informality and politics in Latin America and the Caribbean}

\subsection{Structure}

The pandemic has negatively affected, to a greater degree and intensity, the populations that were in more vulnerable positions prior to the arrival of the plague in Latin America (JULIÁN, 2020; ROMO AGUILAR, 2020; CARDOSO; PERES, 2021)13. It is true that the Gini Index of the countries analyzed so far is not correlated with the number of deaths per million people. That is, there appears to be no between countries effect ${ }^{14}$. But inequality seems to be important within each country. Take the Brazilian case. Baqui et al. (2020) show that, excluding age as the main risk factor, black (including mixed race) people have significantly higher risk of mortality than white people. This is not a congenital factor for mortality, of course, but the expression of social inequality instantiated in the skin color of Brazilians ${ }^{15}$.

In the same line of reasoning, Table 2 presents the relation between the mortality rate of people hospitalized with Covid-19 and years of schooling in Brazil|' $^{16}$. The probability of death of those hospitalized was of $31.4 \%$ from March to December 2020. However, if a person was illiterate, s/he was 2.66

\footnotetext{
${ }^{13}$ In no way paradoxical, the pandemic positively affected the opportunities of the very rich: a report produced by Oxfam (2020) showed that, during the pandemic, Latin American billionaires increased their fortune by US\$ 48.2 billion. In Brazil alone, Forbes has recently added eleven new billionaires to its list. https://valor.globo.com/financas/noticia/2021/04/06/brasil-ganha-11-novos-bilionarios-na-lista-da-forbes.ghtml

(accessed May 2021).

${ }^{14}$ We will not present the graph here, but those interested may demand the authors. $\mathrm{R}^{2}$ is 0.005 .

15 See also CEPAL (2021) for the same argument for other L. A. countries with an important presence of Afro-Latin-Americans.

${ }^{16}$ Unfortunately, we couldn't find the same data for other Latin American countries. But see Ponce et al. (2020) for the case of Ecuador, and for Chile, Gil and Undurraga (2020).
} 
times more likely to die than if $\mathrm{s} /$ he had more than 12 years of schooling (equivalent to be at least enrolled in higher education). Note that the probability decreases monotonically as one ascends in the scale of years of schooling, which is a very good measure of the Brazilian social structure17.

Table 2 - Number of Brazilians hospitalized with Covid-19, and mortality rate according to schooling. Brazil, March 01 to December 31, 2020

\begin{tabular}{l|c|c}
\hline \multicolumn{1}{c|}{ Schooling } & $\begin{array}{c}\mathbf{N} \\
\text { hospitalized }\end{array}$ & Mortality rate \\
\hline No schooling / illiterate & 16.384 & 50,9 \\
Up to 5 years & 59.874 & 41,9 \\
6-9 years & 41.267 & 35,1 \\
10-12 years & 71.092 & 24,2 \\
More than 12 years & 35.995 & 19,1 \\
Children & 4.832 & 8,1 \\
Ignored & 205.665 & 31,2 \\
\hline Total & 435.109 & 31,4 \\
\hline
\end{tabular}

Source: SIVEP-Gripe Microdata, available at ttps://opendatasus.saude.gov.br/dataset/bd-srag-2021 (downloaded in May 2021)

In addition to inequality, Latin America is plagued by persistent informality, a constituent element of the structure of life opportunities, by which people earn their income from commercial transactions or from the provision of services through direct physical contact (either on the streets, in popular markets, in small stalls of food or products, in domestic work, etc.). The necessary social distancing policies to prevent the community transmission of the virus fatally harms informal workers' means of obtaining income, as is now well established in the literature ${ }^{18}$.

Though important, it seems clear that these structural constraints are not sufficient explanations of the patterns of incidence and lethality of Covid-19 in the continent.

\subsection{Context}

In the months before Ecuador's first positive Covid-19 case, the country was experiencing a deep political crisis. Street protests surged against the austerity policies adopted by the federal government (a counterpart to loans

\footnotetext{
${ }^{17}$ As shown in Cardoso and Préteceille (2021), if a person has a higher education degree, s/he has $85 \%$ chance of figuring in a middle-class position or higher.

18 See, for example, CEPAL (2020). For the case of South Asia, see World Bank (2020). For sub-Saharan Africa, Nguimkeu and Okou (2021). For a more general argument, ILO (2020).
} 
from the International Monetary Fund). Under the baton of a president with a strong authoritarian temper, thousands of people were arrested. The intensity of the conflicts was such that the president was forced to travel more than 400 kilometers away from his administrative headquarters to escape the popular protests that overcrowded the streets of the country's capital Quito (TRUJILLO, 2020; CHAUCA, 2021).

Chile was affected by the biggest demonstrations recorded since re-democratization. Although strongly repressed by security forces, it is estimated that 1,2 million people marched in protest against the consequences of decades of neoliberalism on social security, education and public health, and demanding a new constitution (GARGARELLA, 2020; SPYER DULCI; ALVARADO SADIVIA, 2021).

In Brazil the extreme right government led by Jair Bolsonaro intimidated democratic institutions with helicopter overflights over the Parliament and the Supreme Federal Court buildings, while stimulating coup demonstrations that called for military intervention. Throughout 2019, the president had also adopted a very conflictive stance against governors of the federation states elected by opposition parties, particularly in the Northeast, in a political context marked by harsh polarization and radicalism.

No less important were the demonstrations against proposals to reform Panama's constitution. Under the pretext of combating corruption, the proposals would expand the federal government's discretionary powers, impose difficulties in readjusting salaries, establish mechanisms to investigate and censor prosecutors and ministers of justice, among others. However, it was the arrival of the new coronavirus in the country that appeased the Panamanian government's quest to implement (neoliberal) constitutional reforms (PEARSON et al. 2021) $)^{19}$.

In Bolivia, democracy had been recently battered with the interdiction of president elect Evo Morales, a coup that brought thousands of people to 
the streets demanding general elections and shouting against the interim (extreme right) government of President Jeanine Áñez Chávez. Her legitimacy has been strongly contested internally, thus making it difficult for her to lead government responses to the pandemic and assure compliance by Evo Morales supporters, the majority of the population ${ }^{20}$.

Though not exhaustive, the examples illustrate some of the countless, to say the least, cyclical difficulties that plagued the region before the arrival of SARS-CoV-2. These difficulties varied in intensity, but what we are suggesting here is that, in many countries, previous institutional and political tensions created unfavorable environments for the reception of the virus, conditioning the possibilities of institutional response.

\section{$4 \quad$ Individual and collective responsibility in Latin America and the Caribbean}

Going a step further in the analysis of the impact of the pandemic in our Region, we propose the notion of responsibility (CARDOSO; PERES, 2021) to cope with the complex relations between structural and context variables that shape the varied institutional responses to the pandemic carried out by different countries in the region.

We name responsibility the set of governments' strategies, at their different levels (municipal, state, and federal), adopted to prevent (or not) the community transmission of the virus and, consequently, reduce (or not) the number of deaths. Our hypothesis is that leadership matters, and that political discourses and practices of those in charge of the management of the pandemic are decisive to its outcomes².

Thus defined, responsibility can be twofold. First, collective responsibility, by which central governments coordinate the discourses and actions of the other governing levels, fostering the adhesion of the

\footnotetext{
${ }^{20}$.www.worldpoliticsreview.com/articles/29032/in-bolivia-politics-and-partisanship-imperil-its-response-to-covid-19 (accessed May 2021). Also Borges (2021).

${ }^{21}$ See Fukuyama (2020). According to him, at the global level, the main factors governing the success of responses to the pandemic have been the States' capacities and resources, social trust and responsibility, and leadership.
} 
population to official sanitary measures. In this type of responsibility, conduct is based on scientific knowledge, and on the idea that all individual actions have collective consequences in terms of the communitarian dissemination of the disease. Governments rely on transparency of official data, promote information campaigns on protection, social distance, and hygiene; combat fake news about forms of transmission, miracle cures and vaccines; insist on the use of personal protective equipment (PPE); and understand that saving lives and saving the economy are not competing targets. In this group, quarantines are more rigid and, therefore, they need to develop direct income transfer programs that cover the largest possible number of the affected population.

A good example of this model of intervention comes from the Argentinean President Alberto Fernandez, who stated that 'It is a time for caring, not for unfounded fears. It is time for scientific evidence, not hearsay. It is time for solidarity, not stigmata. This is an agreement that we Argentines have built: to take care of each and everyone. No one is saved alone'22.

The second type is individual responsibility. It brings together a set of guidelines focused on the treatment and / or remediation of the most serious cases of Covid-19. With more flexible or non-existent quarantines, its focus is mainly on expanding hospitals' infrastructure to prevent the collapse of the health system; promoting drugs instead of protection, hygiene, and social distancing measures; sometimes insisting on the false dilemma between health and the economy; laxity in fighting fake news about the pandemic, and sometimes promoting them extensively. Access to health data is often made difficult, information campaigns are not always nationally coordinated, and there is often denialism of the seriousness of the sanitary crisis. In short, neglect of science as the main guiding light through the mists of the pandemic. In most cases, governments simply relinquish their coordination and management roles.

\footnotetext{
${ }^{22}$ See https://alferdez.com.ar/cuidar-lo-consequido/, published in May 2020.
} 
The clearest example comes from Guatemala, whose President Alejandro Giammattei said, in August 6, 2020: 'We have been busy all this time with the coronavirus. I thank God I am leaving this issue now to be able to return to the issue of governing the country. Today we are transferring responsibility to the people. If the people want to take care of themselves, they will take care' (apud PEARSON et al. 2021:6). Figure 1 summarizes the main dimensions of the two models.

Figure 1: Two models of responsibility

\begin{tabular}{|l|l|}
\hline \multicolumn{1}{|c|}{ Collective responsibility: } & \multicolumn{1}{c|}{ Individual responsibility } \\
\hline $\begin{array}{l}\text { Central governments coordinate the } \\
\text { actions of other administrative levels, } \\
\text { irrespective of political affiliations }\end{array}$ & $\begin{array}{l}\text { Central governments fail to coordinate the actions } \\
\text { of other administrative levels, either purposefully or } \\
\text { due to political conflicts and polarization }\end{array}$ \\
\hline $\begin{array}{l}\text { Actions are transparent and based on } \\
\text { extensive data gathering and diffusion }\end{array}$ & $\begin{array}{l}\text { Actions are most often erratic, based on hearsay or } \\
\text { unfounded convictions }\end{array}$ \\
\hline $\begin{array}{l}\text { The population is convinced and } \\
\text { convoked to adhere to preventive sanitary } \\
\text { measures based mostly on social } \\
\text { solidarity and caretaking }\end{array}$ & $\begin{array}{l}\text { The population is left by itself, and the pandemic is } \\
\text { managed by ex post health treatments (often with } \\
\text { useless medicaments) and investments in hospital } \\
\text { infrastructure }\end{array}$ \\
\hline $\begin{array}{l}\text { Science guides public policies and } \\
\text { discourses }\end{array}$ & $\begin{array}{l}\text { Science denialism prevents the adequate diagnosis } \\
\text { of causes and consequences of the disease }\end{array}$ \\
\hline Fake news is thoroughly combated & Fake news is often a central way of governance \\
\hline
\end{tabular}

We chose 11 Latin American countries to ground these two models ${ }^{23}$. Our hypothesis is that collective responsibility is more effective in taming the pandemic than individual responsibility, irrespective of the structural constraints and of the previous political and institutional environments discussed earlier.

In Table 3 we classify these 11 countries according to the kind of responsibility they have adopted and rank them according to the number of deaths per million inhabitants as of September 2020. Uruguay, Argentina, Colombia and Costa Rica, that chose collective responsibility, had much less deaths per million than Mexico, Ecuador, Panama, Brazil, Chile, Bolivia and Peru, that chose individual responsibility. Note that the death rate in the first group is also positively correlated with informality and seems not to be

\footnotetext{
${ }^{23}$ Further research is mandatory to extend our findings. This means that they must be taken as a hypothesis. In methodological terms, the data used to identify governments' speeches and actions were collected mostly on governments' official websites (especially central governments), between March and September 2020. Additional literature was also consulted as it came to light during the pandemic.
} 
affected by the scope and reach of income transfer programs. That is, informality reduced public policies' effectiveness, but even the highest informal economy in the first group, Colombia, had nearly one third the number of deaths per million than the least informal country in the second group, Chile.

Table 3 - Collective vs individual responsibility in dealing with the pandemic in selected Latin American countries, until September 2020

\begin{tabular}{|c|c|c|c|c|c|c|}
\hline Country & $\begin{array}{l}\text { Deaths/1M } \\
\text { population* }\end{array}$ & $\begin{array}{c}\text { Kind of } \\
\text { Responsibility }\end{array}$ & $\begin{array}{c}\text { Informality } \\
\text { (\%) }\end{array}$ & $\begin{array}{l}\text { Income } \\
\text { Transfer } \\
\text { Programs } \\
\text { (ITP)** }\end{array}$ & $\begin{array}{l}\text { Households } \\
\text { covered by } \\
\text { ITP (\%) }\end{array}$ & $\begin{array}{c}\text { Gini } \\
\text { (circa } \\
\text { 2018) }\end{array}$ \\
\hline Uruguay & 12,6 & \multirow{4}{*}{ Collective } & 23,9 & 0,06 & 5,1 & 39,7 \\
\hline Costa Rica & 88,2 & & 36,6 & 0,09 & 6,1 & 48 \\
\hline Argentina & 354,7 & & 49,4 & 8,8 & 66,2 & 41,4 \\
\hline Colombia & 390,4 & & 62,1 & 2,6 & 19,3 & 50,4 \\
\hline Panama & 464,1 & \multirow{7}{*}{ Individual } & 52,8 & 0,55 & 45,8 & 49,2 \\
\hline Bolivia & 549,3 & & 84,9 & 1,6 & 55,2 & 42,2 \\
\hline Brazil & 573,6 & & 47,1 & 29,4 & 43 & 53,9 \\
\hline Ecuador & 574,3 & & 63,5 & 0,95 & 1,9 & 45,4 \\
\hline Chile & 587,8 & & 25,3 & 1,8 & 31,8 & 46,4 \\
\hline Mexico & 596,8 & & 65,9 & - & - & 45.4 \\
\hline Peru & 871,0 & & 68,4 & 0,8 & 2,5 & 41,9 \\
\hline
\end{tabular}

\subsection{Collective Responsibility}

Shortly after the first death record in Argentina (also the first in South America), borders were closed, classes were suspended, and the population was strictly quarantined, which was successively extended for many months. President Alberto Fernández placed himself at the core of the sanitary actions, coordinating the policies of the other federative levels and assuming the pandemic as a federal government responsibility. Compliance was facilitated by the large legitimacy of his mandate, recently obtained in the first round (more than $48 \%$ of the votes) against his competitor, President

\footnotetext{
${ }^{24}$ The sources are WorldoMeter, International Labour Organization, Euromonitor, Governments websites, World Bank, Coronatracker.com, Economic Commission for Latin America and the Caribbean (CEPAL); Fraschina (2020); e Gentilini (2020).
} 
Mauricio Macri, who was running for a second office ${ }^{25}$. The three levels of government coordinated various actions, including the building, in 45 days, of 12 modular hospitals in the most populous districts of the country. Of particular interest was the (unexpected, given the country's political polarization) coordination between the federal government and municipalities in ensuring compliance to the strict quarantines (RAMÍREZ DE LA CRUZ, 2020). Mass media were strongly activated to mobilize the Argentines in favor of the restrictive policies, and actions were tightly coordinated and negotiated across governing levels.

Colombia also suspended classes, closed borders and built large-scale field hospitals to shelter patients with least severe forms of the disease, so that ICU facilities could remain available to those in need of intensive care or mechanical ventilation. In coordination with provincial and federal authorities, some cities adopted strict lockdowns ${ }^{26}$. Three weeks after the first death in the country, the president explained to the population that the dilemma between the economy and health is nonexistent; without health there is no economy and without the economy, public health will suffer: 'finding a balance between these two crucial objectives has become the government's main goal'27. According to Blofield, Giambruno and Filgueira (2020), large Colombian cities supported and complemented the measures proposed by the federal government. For example, Bogotá transferred income to approximately 337,000 poor and vulnerable families; and Medellín established an infrastructure to assist people to electronically request food and cash transfers. That is, public authorities coordinated their actions both in bottom up (from cities to the federal government) and top down sanitary strategies.

In Uruguay, in addition to strict and long quarantines ${ }^{28}$, one of the first institutional strategies was the cancellation of presential classes and the

\footnotetext{
${ }^{25}$ For a comprehensive analysis of the Argentine case, see Grimson et al (2021). Albeit sponsored by the federal government, the volume offers a varied perspective on the crisis and its aftermath.

${ }^{26}$ See, for instance, Minsalud (2020).

27 https://www.youtube.com/watch?v=8Ga4Kal-ilc\&ab_channel=AtlanticCouncil (accessed May 2020).

28 For instance, touristic facilities such as thermal centers staid closed until July 2020, casinos until August and so on. And Uruguay has been the first L. American country to return to presential classes, in July 2020 , locking down again when the second wave hit in October.
} 
announcement of distance learning plans using the computers and online tools previously provided by the Ceibal Plan (its slogan was 'one laptop per child') ${ }^{29}$. Schools should remain open only to provide meals for students ${ }^{30}$. In the first few weeks after the first confirmed case, the federal government announced the Fondo Coronavirus ${ }^{31}$ to finance the fight against the pandemic. It is worth mentioning that part of the funding came from public companies and contributions of senior positions in the civil service - such as the transfer of $20 \%$ of the president's, ministers', and legislators' salaries, including those of opposition parties. Though negligeable in financial terms, the initiative denoted that, regardless of political orientation, there was cohesion among public authorities to combat Covid-19. These gestures to encourage adhesion to social distancing campaigns were repeated to exhaustion ${ }^{32}$. The government has also campaigned in the mass media daily convoking the adhesion of the population to the scientifically informed sanitary measures adopted ${ }^{33}$. No wonder, a few days after the first death in the country, the president delivered a speech on national television calling everyone to address the pandemic with a Uruguayan 'spirit', meaning 'with solidarity, and thinking of the common good'34. The country also paid special attention to cases of Covid-19 in prisons, for example ${ }^{35}$.

In Costa Rica, in just over a week from the first confirmed case, the federal government suspended classes in schools and universities and, in agreement with the other republican powers, granted the police sanitary authority to close commercial establishments ${ }^{36}$. In two weeks, the country

\footnotetext{
${ }^{29}$ Plan Ceibal available at https://www.siteal.iiep.unesco.org/sites/default/files/sit_accion_files/siteal_uruquay_5043.pdf (accessed Jul. 2020).

30 https://www.elpais.com.uy/informacion/educacion/mil-anotaron-comer-escuela.html (accessed Aug. 2020).

${ }^{31}$ https://www.presidencia.gub.uy/sala-de-medios/videos/conferencia-

32 As the photos of the current president (center-right) visiting the house of the former president (center-left) to talk about the best ways to fight the pandemic in the country. https://twitter.com/matiasponce/status/1265320548151820290 (accessed May 2020).

$33 \mathrm{See}$, for instance, the decree 495 of May 2021, in https://www.impo.com.uv/bases/resoluciones/495-2020. (accessed Oct. 2021).

34 "El Gobierno está pensando en el día después mientras trabaja para los uruguayos que necesitan una voz de tranquilidad". https://www.presidencia.gub.uy/sala-de-medios/videos/ag_136 (accessed Sept. 2021).

${ }^{35} \mathrm{~A}$ comparison between Uruguay, Sweden and Japan as examples of liberal-communitarian responses to the Covid-19 is Etzioni (2021). Also very important was the development of an app to trace the infected, ready from March 20, 2020. See Winch et al. (2021).

${ }^{36}$.https://www.ministeriodesalud.go.cr/index.php/centro-de-prensa/noticias/741-noticias-2020/1571-ante-covid-19-lin eamientos-se-endurecen-con-el-cierre-total-de-bares-discotecas-y-casinos (accessed May 2021).
} 
closed borders and restricted the circulation of vehicles and people. Thanks to the infrastructure of the public health network and rapid communication between public authorities, epidemiologists and other specialists, the country immediately adopted measures to monitor and track cases, the data of which subsidized government's decisions and provided more efficient quarantines. According to Enríquez and Sáenz (2021), the country was the first in Latin America to invest in research to produce tests and laboratory kits to reduce a foreseeable dependence on the international market. Work groups in government institutions (at different levels), research centers, private companies and universities were formed to propose solutions. For example, in just over a month, the National Liquor Factory in partnership with the University of Costa Rica started to produce antiseptics ${ }^{37}$, which were distributed to the entire Costa Rican population through the national mail delivery system.

The four countries adopted strict and long lasting national quarantines (in Argentina it lasted 5 full months, 4 months in Uruguay) and coordinated local lockdowns, mobilized civil society's organizations to foster adhesion to restrictive measures, central governments coordinated the actions of the other administrative levels, including exhaustive campaigns in the mass media; and adopted cash transfer programs that, either targeting the unemployed or the informal and vulnerable workers (such as in Uruguay and Costa Rica), or being more comprehensive and favoring larger portions of the population (Argentina and Colombia), have made it possible for the population to comply with more restrictive quarantines and lockdowns. Most importantly, the population was convinced to adhere to the restrictive measures.

\footnotetext{
${ }^{37}$.https://www.ucr.ac.cr/noticias/2020/04/24/la-fabrica-nacional-de-licores-y-la-ucr-se-dan-la-mano-para-optimizarla-produccion-de-alcohol.html (accessed May 2021).
} 


\subsection{Individual responsibility}

Differently enough, Chile, Ecuador, Peru, Brazil, Panama, Bolivia, and Mexico have chosen to direct their efforts towards individual responsibility to combat the pandemic, either on purpose or as a consequence of flawed governance.

Chile had faced strong political turmoil at the doors of the pandemic, and in spite of the emergency powers granted to the central government by the authoritarian constitution inherited from the Pinochet dictatorship, and despite president Piñera's intent to centrally coordinate the various administrative levels, the population resisted the isolation measures, and coordination was actually impossible. The so-called 'dynamic lockdown', that restricted circulation only in specific neighborhoods, instead of entire municipalities, was a complete failure, and it contrasted with the violence of the armed forces on the streets, imposing a curfew between $10 \mathrm{pm}$ and 5 am in the beginning of the pandemic. The aim was, allegedly, to prevent circulation, theft, and looting, but it actually blocked the mounting wave of political protests. Low adherence to individual isolation, for many needed to keep on working (JULIÁN, 2020), combined with insufficient provision of new beds for hospitalization (for Covid-19 and other diseases) resulted in the collapse of hospitals with a consequent increase in deaths, something experts had already warned (BACIGALUPE et al., 2020). As stated by Campos, Chambeaux and Espinoza (2021:156), "[w]himsical public policies focused on maintaining large-scale production and trade, leaving small producers unprotected, has been the main line of government work, leaving each person and each community to solve in the best possible way, but without state support, the problems derived from COVID-19" (emphasis added).

Peru established a different isolation policy, but with remarkably similar results. In the early days of the virus in its territory, an inflexible quarantine policy was established, with armed forces' barriers between municipalities, police patrol, mandatory use of masks, establishment of fines and specific 
days for men or women to leave the house to buy goods or essential services. The sudden and rigid restrictions, however, had an opposite effect in comparison to the countries that chose collective responsibility by means of persuasion. Hundreds of thousands of people were unable to return to their homes and had no money to stay in the cities they were confined to ${ }^{38}$. This forced a considerable number of Peruvian workers to walk in large groups for days, gathering in hostels, pensions and on the streets and roads, exposing themselves to both the virus and the army's brutality. And while the country quickly announced a series of programs aimed at the poorer populations, rural and self-employed workers, the "Bono "Yo me quedo en casa"' reached only $2.5 \%$ of the Peruvian families, thus making it impossible for informal workers, the vast majority in the country, to stay home ${ }^{39}$. They had to return to public markets and streets to make their living, thus fueling the pandemic. Besides, there has been a clear lack of coordination between national and regional authorities, and '[M]any regional governments operated independently, providing different recommendations to their constituents or even rejecting the imposed focalized lockdown' (SCHWALB and SEAS, 2021:1176). As a consequence, the population had to find individual ways to escape the virus, and among these were ineffective drugs such as Hydroxychloroquine and Ivermectin, easily bought in drugstores without prescriptions (id., ibid.).

Ecuador suspended school classes, closed borders, made constant official pronouncements, decreed a curfew, but was unable to establish an effective social isolation policy, in particular because, with 4,4 million people in poverty or extreme poverty, the 'Bono de Protección Familiar' (US\$ 60) covered only 950,000 Ecuadorians. And only for two months. People had to resume informal work. As a result, in less than a month the hospital system collapsed and, with it, the funerary system (CHAUCA, 2021). Many bodies of people killed by Covid-19 in the city of Guayaquil were plundered on the streets and parks or stayed for days at home awaiting a public authority to

\footnotetext{
${ }^{38}$.https://www7.folha.uol.com.br/mundo/2020/04/medidas-duras-contra-covid-19-no-peru-esbarram-em-problemas -sociais.shtml (accessed May 2021). See also Delgado (2020) and Lanza et al (2020).

39 https://informacion.yomequedoencasa.pe/ (accessed May 2021)
} 
collect them ${ }^{40}$. That is, despite the government's inclination to collective responsibility, as shown by the initially (quite) restrictive policies, they proved rather timid vis-à-vis the country's needs (see also PONCE et al. 2020). Besides, president Lenín Moreno faced harsh opposition in a very polarized political environment, making it difficult to coordinate the actions of the various administrative levels

(CONDE,

PRADA-ESPINEL; PULLAGUARI-ZARUMA, 2021).

For its part, Panama was the first country in Central America to confirm a death by Covid-19 (March 10, 2020) ${ }^{41}$. A few days later the federal government closed the border with Europe, decreed the suspension of religious and cultural activities and declared a state of emergency. However, contrary to what the term emergency suggests, government initiatives were very timid and practically focused on mandatory quarantine, which, as in Peru, was also based on gender. Under the surveillance and control of the security forces, the argument offered by the federal government to justify this criterion was that the public agent could 'easily' distinguish men and women. It did not take long for accusations of discrimination, harassment and physical violence against LGBTQI+ people to arise. After months of neglecting the numerous and growing accusations, the minister responsible for public security in the country recognized the seriousness of the situation 42.

In any case, Panama is one of the most unequal countries in the region (behind only Brazil and Honduras) and more than half of its workforce is informal. However, the mandatory use of masks in public spaces, for example, was only approved in June 2020. As a result, in less than three months of SARS-Cov-2 in its territory, Panama became the Latin American country with the highest number of deaths proportional to the population (PEARSON et al., 2021). In September, the mortality rate was of 464 deaths

\footnotetext{
${ }^{40}$.https://al.globo.com/bemestar/coronavirus/noticia/2020/04/05/com-corpos-de-mortos-por-coronavirus-nas-ruascidade-do-equador-recebe-doacao-de-mil-caixoes-de-papelao.ghtml (accessed May 2021)

${ }^{41}$.https://www.straitstimes.com/world/americas/panama-records-central-americas-first-coronavirus-death (accessed May 2021)

42.https://www.hrw.org/news/2020/06/16/panama-took-positive-step-transgender-peoples-rights (accessed May 2021)
} 
per million inhabitants, almost 5.4 times higher than the neighbor Costa Rica (87 per million), that adopted collective responsibility ${ }^{43}$.

Bolivia is an apparent deviant case, for, like Ecuador, its initial responses to the pandemic followed the social responsibility model. The country quickly decreed a national quarantine (the violation of which could lead to imprisonment for eight hours), limiting hours of public and private transportation, establishing specific opening hours for essential services with limited use of one person per family. Subsequently, it prohibited the suspension of services such as water, electricity, and internet due to default, and reduced electricity tariffs. Besides, the cash transfer programs created by the Evo Morales administrations helped to reduce the urge to work for more than $80 \%$ of people in the informal economy (BORGES, 2021). But political and institutional conflicts $^{44}$ between a president considered illegitimate by most of the population that had voted for the evicted Evo Morales, and provinces and municipalities, made it difficult to assure compliance to state sponsored measures and to coordinate the actions of the various administrative levels ${ }^{45}$. And Bolivia, Ecuador and Peru have all failed to properly access and protect non-Spanish speaking indigenous populations (GARCIA et al., 2020).

The Brazilian case is similar, in some respects, to the Bolivian one. The federal government also considered following WHO guidelines (collective responsibility) when it counted only a few positive cases. However, the signs that the pandemic would inevitably impact the country's (meager) economic results reoriented the federal government's strategies and speeches. President Bolsonaro denied the seriousness of the disease, and repeatedly prompted Brazilians to return to work to save the economy. He also neglected the deaths, and when the dead reached 100 thousand, he

\footnotetext{
43 For a joint analysis of the Central-American countries, see Enríquez and Sáenz (2021).

${ }^{44}$ For example, on May 11th, the federal government tried to implement a 'dynamic quarantine'. However, most of the country's departments decided to maintain the measures of confinement (BLOFIELD, GIAMBRUNO; FILGUEIRA, 2020. p. 46).

45 Note that there is clear evidence of underreporting of deaths by Covid-19 in the Bolivian case. According to Karlinsky and Kobak (2021), data on excess mortality suggest that Bolivia was the second in the world in terms of death per 100 thousand inhabitants, behind Peru only. So, this would put Bolivia far down Table 2, above, in the individual responsibility rank.
} 
just said that 'life must go on. We must find our way out of this problem'46. And just like in Bolivia, conflicts between federative levels and political polarization made coordination of actions impossible.

It is true that measures to alleviate the consequences of the pandemic in the formal and informal sectors have been much stronger than those of most Latin American countries. But they reduced workers' income from $40 \%$ to $90 \%$ of the original figures, thus making it impossible for the informal workers to stay home (CARDOSO; PERES, 2021). The president also preached repeatedly against lockdowns and in favor of Hydroxychloroquine and Ivermectin while prompting Brazilians to return to work and face the virus 'like men'47, that is, without the fear of being infected.

Finally, Mexico was the last Latin American country to establish measures of social distancing to contain the community transmission of the virus. State and municipal governments and civil society entities faced the difficulties of proposing measures to protect the population while dealing with a persistently denialist president. On March 15, when the country had 44 confirmed cases, Andrés López Obrador urged people to live their 'normal lives' and affirmed that the Mexicans made up a strong ethnic community and that, for this reason, they would overcome Covid-19 just as other pests. López Obrador was seen wearing a protective mask for the first time on a commercial flight to Washington (USA) only in July, when the country had already recorded more than 32,000 deaths from Covid-19. The main local measures were enacted without the coordination of the federal government ${ }^{48}$.

In fact, Mexico City was the first to enact quarantine and other measures to restrict circulation in the capital, followed by the governor of Jalisto and seven other Mexican states that, in addition to restrictions on the circulation of persons, also suspended flights, particularly from the USA.

\footnotetext{
${ }^{46}$.https://www7.folha.uol.com.br/equilibrioesaude/2020/08/vamos-tocar-a-vida-diz-bolsonaro-sobre-iminencia-de-10 0-mil-mortes-por-covid-19.shtml (accessed May 2021).

${ }^{47}$.https://noticias.uol.com.br/ultimas-noticias/agencia-estado/2020/03/29/bolsonaro-diz-que-e-preciso-enfrentar-vir us-como-homem-e-nao-como-moleque.htm (accessed May 2021).

48 See Sánchez-Talanquer et al. (2021, pp 52 ff).
} 
Ineffectively enough, López Obrador tried to stop layoffs due to the crisis and decided only to anticipate the payment of disability pensions, and to offer credit ('Tandas para Bienestar') to people and companies, through social security (in the case of formal ones) and for informal family micro-enterprises. However, despite the promise of the federal government's microcredit program to serve 4 million people, only 1,5 million obtained it, the value of which did not exceed \$1,100 dollars. On April 13, 'Bono Covid-19' was awarded to health professionals who, until January 6, passed on a $20 \%$ increase in salaries to 160,000 hospital workers who dealt directly with the pandemic. No relief money or credit was adopted for the poorer portions of the population. It is no wonder that, of the 53 economies with GDP that exceed US\$200 billion analyzed by Bloomberg, in late November 2020 Mexico was considered the worst country of all to be during the pandemic ${ }^{49}$

In short, Mexico and Brazil, with their denialist presidents (of science, of the seriousness of the disease, of the effectiveness of protective equipment, and later, of the vaccines...), are the most clear-cut cases of a nationally fostered policy based on 'everyone for oneself'. In the other five cases, taking care of oneself was the consequence of public authorities incapacity (or unwillingness in the cases of political polarization, such as Bolivia, Peru and Ecuador) to coordinate their actions and offer the population clear and unambiguous guidelines for action. Here, high informality rates combined with insufficient money transfer policies, have forced the population back on the streets to make their living, in many cases counting on miraculous cures from ineffective medicaments, since the healthcare systems (public and private) collapsed everywhere.

\section{$5 \quad$ Final remarks: the open veins by covid-19 in Latin America}

We believe that we have presented enough elements to maintain that the heuristic value of counting cases/deaths is, at the very least,

${ }^{49}$.https://www.bloomberg.com/news/videos/2020-17-25/coronavirus-pandemic-the-best-and-worst-places-to-be-vid eo (accessed Sept. 2021). 
unsatisfactory. Taken alone (therefore, disregarding the structure and context), the proportion of cases and deaths tends to cloud the heterogeneity of government policies and institutional guidelines adopted in the Region. The main consequence is that it hinders the correct assessment of the policies (and their proponents) who were 'allies' of the virus, as well as to positively evaluate decisions that have saved lives - and whose measures could be replicated in other countries, states and/or municipalities/provinces.

Colombia, for example, has an average of meager 10 points in the Covid Performance Index, which puts it in the 100th position in the world ranking. The hurried researcher, overshadowed by the number of deaths (and related variables, such as confirmed cases and testing) could ask what can a country with such a low performance in combating the pandemic teach us? Part of the answer is, as we have seen, that the Colombian federal government has adopted measures of collective responsibility. Among them, there was the decree that allowed a regulatory center (such as a city hall) to officially assume the administration and control of all intensive care units of public and private hospitals, "para que cada ciudadano tenga la misma oportunidad del derecho a la salud'so. If replicated in other countries, this measure would have the potential to save the lives of people who died from lack of ventilators, as well as those who sought hospitalization too late because they feared debt ${ }^{51}$.

Centralization and coordination of actions also seems to have been crucial $^{52}$. It is undeniable that, although the creation of different income transfer programs is observed in Latin America - be them direct, focusing on informal workers, domestic workers, unemployed, small self-employed workers and beneficiaries of past income transfer policies; or indirect, by https://www.seattletimes.com/seattle-news/inspiring-story-of-seattle-mans-coronavirus-survival-comes-with-a-1-1million-dollar-hospital-bill/ (accessed May 2021).

52 On the effect of leadership on the consequences of the pandemic for the Brazilian case, see Fernandes et al. (2020) and Rache et al. (2021). For a worldly assessment, Fukuyama (2020). 
means of credit for companies -, the most successful countries in combating the pandemic, at least in its first wave (up to September 2020), were those that adopted some sort of collective responsibility with central coordination of the governing levels, irrespective of party affiliation vis-à-vis the incumbents in power. That is, these countries implemented a set of institutional strategies that prioritized, above all, prevention, to halt or reduce the speed of communitarian transmission of the virus. There, adhesion to social isolation was, to a large extent, obtained by persuasion through public authorities' frequent and transparent pronouncements and official publicity campaigns on the indispensability of personal protective equipment, upkeeping personal hygiene. The population was convinced by scientifically supported statements, to voluntarily engage in the safety measures put forward by the public authorities. Collective responsibility intends to guarantee, above all, the lives of citizens, keeping them away from the virus or preventing the collapse of the health system. It does, however, require continuous governmental effort and society's adherence. Otherwise, it is hard for the former to resist pressures from economic sectors, the civil society, politicians, etc., so that the country 'returns to normality'.

\section{References}

ABBEY, Enoch J. et al. The Global Health Security Index is not predictive of coronavirus pandemic responses among Organization for Economic Cooperation and Development countries. PLoS ONE Vol. 15, No. 10: e0239398, 2020. DOl.org/10.1371/journal.pone.0239398.

ASONGU, Simplice; DIOP, Samba; NNANNA, Joseph.. Health vulnerability versus economic resilience to the Covid-19 pandemic: Global evidence. AGDI Working Paper, No. WP/20/074, African Governance and Development Institute (AGDI), 2020. Available at: http://www.afridev.org/RePEc/agd/agd-wpaper/Health-Vulnerability-versus-Econom ic-Resilience-to-the-Covid-19-pandemic.pdf. Access in: May 21, 2021.

BACIGALUPE, Gonzalo. et al. O desastre chegou ao Chile: A falida estratégia de combate à pandemia de Covid-19. Blog DADOS, 2020. Available at: http://dados.iesp.uerj.br/chile-pandemia. Access in: July 20, 2020.

BAQUI, Pedro. et al. Ethnic and regional variations in hospital mortality from COVID-19 in Brazil: a cross-sectional observational study. The Lancet Global Health, 
Vol. 8, No. 8, p. e1018-e1026, 2020. Available at: https://www.sciencedirect.com/science/article/pii/S2214109X20302850. Access in: May 21, 2021.

BLOFIELD, Merike; GIAMBRUNO, Cecilia; FILGUEIRA, Fernando. Policy expansion in compressed time: Assessing the speed, breadth and sufficiency of post-COVID-19 social protection measures in 10 Latin American countries. Santiago de Chile, CEPAL, 2020. Available at: https://repositorio.cepal.org/handle/11362/46016. Access in: Sept. 14, 2021.

BORGES, Fabián A. Bolivia's social policy response to Covid-19: Hindered by political and economic crises. CRC 1342 Covid-19 Social Policy Response Series, 19 Bremen: CRC 1342, 2021.

CAMPOS, Luiz; CHAMBEAUX, Javiera; ESPINOZA, Claudio. Incidência de COVID - 19 em povos indígenas e afrodescendentes do chile e autogestão comunitária. Albuquerque: revista de história, Vol. 13, No. 25, p. 143-158, 26 abr. 2021. DOl.org/10.46401/ardh.2021.v13.12536.

CARDOSO, Adalberto; PERES, Thiago B.. "Brazil, South America and Covid-19", in PIETERSE, J. et al. (eds). Covid-19 and Governance: Crisis reveals. London: Routledge. 2021.

CARDOSO, Adalberto; PRÉTECEILLE, Edmond. Classes médias no Brasil. Estrutura, mobilidade social e ação política. Rio de Janeiro: UFRJ, 2021.

CEPAL (COMISIÓN ECONÓMICA PARA LA AMÉRICA LATINA Y CARIBE). América Latina y el Caribe ante la pandemia. Efectos económicos y sociales. Informe Especial COVID-19, No. 1, 2020. Santiago de Chile: CEPAL.

CEPAL (COMISIÓN ECONÓMICA PARA LA AMÉRICA LATINA Y CARIBE). LaS personas afrodescendientes y el COVID-19: develando desigualdades estructurales en América Latina. Informes CoviD-19, jan. 2021. Available at: https://www.cepal.org/es/publicaciones/46620-personas-afrodescendientes-covid-19 -develando-desigualdades-estructurales. Access in: May 21, 2021.

CHAUCA, Roberto. La Covid-19 en Ecuador: fragilidad política y precariedad de la salud pública. História, Ciências, Saúde-Manguinhos [online], v. 28, n. 2 pp. 587-591, 2021. Available at: DOl.org/10.1590/S0104-59702021005000003.

CONDE, Manuel A.; PRADA-ESPINEL, Oscar A.; PULLAGUARI-ZARUMA, Kevin P. Comunicación gubernamental pre-covid de los presidentes hispanohablantes en Twitter Pre-covid government communication of spanish-speaking presidents on Twitter. Universitas, No. 34, pp. 63-86, marzo-agosto, 2021.

DELGADO, Deborah. La Covid-19 en el Perú: una pequeña tecnocracia enfrentándose a las consecuencias de la desigualdad. Análisis Carolina No. 26, Fundación Carolina, 2020. Available at: https://www.fundacioncarolina.es/wp-content/uploads/2020/05/AC-26.-2020.pdf. Access in: Sept. 14, 2021.

ELGIN, Ceyhun et al. Economic policy responses to a pandemic: Developing the COVID-19 Economic Stimulus Index. VOXEU.Org, 2020. Available at: 
https://voxeu.org/article/economic-policy-responses-pandemic-covid-19-economic-s timulus-index. Access in: May 21, 2021.

ENRÍQUEZ, Alberto; SÁENZ, Carlos. Primeras lecciones y desafíos de la pandemia de COVID-19 para los países del SICA. Estudios y perspectivas. Serie 189, Santiago de Chile: CEPAL, 2021. Available at: https://www.cepal.org/sites/default/files/publication/files/46802/S2100201_es.pdf. Access in: May 21, 2021.

ETZIONI, Amitai. Community and COVID-19: Japan, Sweden and Uruguay. Global Politics and Strategy, Vol 63, 2021. DOI.org/10.1080/00396338.2021.1881254.

FERNANDES, Ivan et al. Ideology, isolation, and death. An analysis of the effects of bolsonarism in the covid-19 pandemic. SSRN Papers, July 2020. Available at SSRN: https://papers.ssrn.com/sol3/papers.cfm?abstract_id=3654538. Access in: Apr. 18, 2021.

FRASCHINA, Santiago. Infografía. Observatorio de Políticas Públicas. Protección Social. Universidade Nacional de Avellaneda. 2020. Available at: https://www.undav.edu.ar/index.php?idcateg=198. Access in: July 27, 2021.

FUKUYAMA, Francis.. La pandemia y el orden político. Foreign Affairs [on line]. vol. 99 n. 4 , jul.-aug. 2020. Available at: https://www.foreignaffairs.com/articles/world/2020-06-09/pandemic-and-political-or der. Access in: Sept. 14, 2021.

GARCIA, GERARDO M. Miscommunication in the COVID era. Bulletin of Latin American Research, Vol. 39, No. S1, pp. 39-46, 2020.

GARGARELLA, Roberto. Diez puntos sobre el cambio constitucional en Chile. Nueva Sociedad, No. 258, 2020. Available at: https://nuso.org/articulo/diez-puntos-sobre-el-cambio-constitucional-en-chile/. Access in Sept 14, 2021.

GENTILINI, Ugo et al. Social Protection and Jobs Responses to COVID-19. World Bank Group. 2020 Available at: https://openknowledge.worldbank.org/handle/10986/33635. Access in: July 27, 2021.

GIL, Magdalena; UNDURRAGA, Eduardo A. COVID-19 has exposed how 'the other half' (still) lives. Bulletin of Latin American Research, Vol. 39, No. S1, pp. 28-34, 2020.

GRIMSON, Alejandro. et al. El futuro después del Covid-19. Buenos Aires: Jefatura de Gabinete de Ministros, 2021. Available at https://www.argentina.gob.ar/sites/default/files/el_futuro_despues_del_covid-19.pdf. Accessed Sept. 2021.

ILO (INTERNATIONAL LABOUR OFFICE). COVID-19 crisis and the informal economy. Immediate responses and policy challenges. Geneva: International Labour Office, 2020. Available at: https://www.ilo.org/wcmsp5/groups/public/---ed_protect/---protrav/---travail/docume nts/briefingnote/wcms_743623.pdf. Access in: May 19, 2021.

JULIÁN, Dasten. Precariedad como gobierno de la pandemia: La experiencia de la precariedad laboral en Chile. Hybris Revista de Filosofía, Vol. 11, No. Especial, 2020. 
KARLINSKY, Ariel; KOBAK, Dmitry. The World Mortality Dataset: Tracking excess mortality across countries during the COVID-19 pandemic. MedRxvi pre-print, 2021. Available at: https://www.medrxiv.org/content/10.1101/2021.01.27.21250604v1.full.pdf. Access in: Sept. 14, 2021.

LANZA, Llerena et al. Emergencia, gestión, vulnerabilidad y respuestas frente al impacto de la pandemia COVID-19 en el Perú. Pre-print Scielo, 2020. Available at: https://preprints.scielo.org/index.php/scielo/preprint/download/94/129/116. Access in: Sept. 14, 2021.

MINSALUD (MINISTERIO DE SALUD Y PROTECCIÓN SOCIAL). Minsalud presenta plan territorial para el control del coronavirus. March 4. 2020. Available at: https://www.minsalud.gov.co/Paginas/Minsalud-presenta-plan-territorial-para-el-co ntrol-delcoronavirus.aspx. Access in: Oct. 19, 2021.

NGUIMKEU, Pierre; OKOU, Cedric. Does informality increase the spread of COVID-19 in Africa? A cross-country examination. Applied Economics Letters, 2021. DOI: 10.1080/13504851.2021.1910128.

NUCLEAR THREAT INITIATIVE, JOHNS HOPKINS CENTER FOR HEALTH SECURITY, THE ECONOMIST INTELLIGENCE UNIT. Global Health Security Index, 2019. Available at: https://www.ghsindex.org/ Access in: May 21, 2021.

OXFAM. Quem paga a conta? Taxar a riqueza para enfrentar a crise da Covid-19
na América Latina e Caribe. 2020. Available at: https://d2v21prk53tg5m.cloudfront.net/wp-content/uploads/2021/04/cms_files_115321 _15997803591595622094Nota_informativa_da_Oxfam_Quem_Paga_a_Conta.pdf. Access in: May 21, 2021.

PEARSON, Andy A. et al. The puzzle of COVID-19 in Central America and Panama. Journal of Global Health 11:03077, 2021. Available at: https://www.jogh.org/documents/2021/jogh-11-03077.pdf. Access in: Sept. 14, 2021.

PONCE, Pablo et al. Efecto de la desigualdad y la actividad económica en el COVID-19 en Ecuador: un bosquejo de sus posibles determinantes económicos, sociales y demográficos. Contaduría y Administración, Vol. 65, No. 4, Especial COVID-19, pp. 1-13, 2020.

RACHE, Beatriz et al.. Quantas vidas cabem em um voto? Nota Técnica, No. 18, São Paulo: IEPS. 2021. Available at: https://ieps.org.br/wp-content/uploads/2021/04/IEPS_NT18.pdf. Access in: May 21, 2021.

RAMÍREZ DE LA CRUZ, Edgar E. et al. The Transaction Costs of Government Responses to the COVID-19 Emergency in Latin America. Public Administration Review, Vol. 80, No. 4, 2020, p. 683-695. Available at https://onlinelibrary-wiley.ez83.periodicos.capes.gov.br/doi/full/10.1111/puar.13259.

Access in Oct. 19, 2021.

ROCHA, Rudi et al. Effect of socioeconomic inequalities and vulnerabilities on health-system preparedness and response to COVID-19 in Brazil: a comprehensive analysis. The Lancet Online, 2021. DOl.org/10.1016/S2214-109X(21)00081-4. 
ROMO AGUILAR, María de L. "Mapeando la vulnerabilidad social ante el COVID-19", in CONTRERAS, Oscar ed. Ciencias sociales en acción: respuesta frente al COVID-19 desde el norte de México. Tijuana: El Colegio de la Frontera Norte, 2020.

SÁNCHEZ-TALANQUER, Mariano et al. La respuesta de México al CoVID-19: estudio de caso. San Francisco: Institute for Global Health Sciences, 2021. Available at:https://globalhealthsciences.ucsf.edu/sites/globalhealthsciences.ucsf.edu/files/la_r espuesta_de_mexico_al_covid_esp.pdf. Access in Sept. 14, 2021.

SCHWALB, Alvaro; SEAS, Carlos. The COVID-19 pandemic in Peru: What went wrong?. The American Journal of Tropical Medicine and Hygiene, v. 104, n. 4, p. 1176, 2021.

SPYER DULCI, Teresa M.; ALVARADO SADIVIA, Vania. (2021). El estallido social en Chile: ¿Rumbo a un Nuevo Constitucionalismo? Katálysis Vol. 24, No. 1, pp. 43-52, 2021. DOI.org/10.1590/1982-0259.2021.e73555.

TETELBOIN, Carolina et al. (Eds.). América Latina: Sociedad, política y salud en tiempos de pandemias. Buenos Aires: CLACSO, 2021.

TRUJILLO, Patricio. Si salimos nos mata el virus, si nos quedamos nos mata el hambre. Cadernos de Campo, Vol. 29, No. Supl. p. 85-93, 2020. Available at: DOl.org/10.11606/issn.2316-9133.v29isuplp85-93.

WINCH, Graham et al. Operation Warp Speed: Projects responding to the COVID-19 pandemic. Project Leadership and Society, Vol.2, 2021. Available at: https://www.sciencedirect.com/science/article/pii/S2666721521000132. Access in: Sept. 14, 2021.

WORLD BANK. Beaten or broken? Informality and COVID-19. New York: World Bank, 2020.

https://openknowledge.worldbank.org/bitstream/handle/10986/34517/978146481640 6.pdf. Access in: May 21, 2021. 